\title{
Increased expression of Mer tyrosine kinase in circulating dendritic cells and monocytes of lupus patients: correlations with plasma interferon activity and steroid therapy
}

Brendan A Hilliard ${ }^{1,2}$, Gaetano Zizzo ${ }^{1,2}$, Mehriban Ulas ${ }^{1,2}$, Margaret K Linan ${ }^{3}$, Jessica Schreiter ${ }^{4}$ and Philip L Cohen ${ }^{1,2^{*}}$

\begin{abstract}
Introduction: The requirement for the immunoregulatory Mer tyrosine kinase (Mer) for optimal removal of apoptotic cells prompted us to look at its expression in systemic lupus erythematosus (SLE), in which apoptotic cell clearance is abnormal. We compared the levels of expression of Mer in normal human subjects and in patients with SLE.

Methods: We used flow cytometry of isolated peripheral blood mononuclear cells to compare the levels of Mer on leukocyte subsets. We used a Mer-specific enzyme-linked immunosorbent assay (ELISA) to quantify soluble Mer (sMer) in plasmas.

Results: Monocytes, $C D 1 c^{+}$myeloid dendritic cells (mDCs), and plasmacytoid dendritic cells (pDCs) from both normal individuals and from SLE patients expressed Mer. In both normal and SLE patients, the CD $14^{++} \mathrm{CD} 16^{+}$ subpopulation of monocytes expressed the highest levels of Mer, with somewhat lower levels on the CD14 ${ }^{\text {int }} C D 16^{+}$ population. Mer levels on $\mathrm{CD}_{1} \mathrm{c}^{+} \mathrm{mDCs}$ and $\mathrm{pDCs}$, and sMer levels in blood were increased in SLE patients compared with controls. In patients, Mer levels on $\mathrm{CD} 14^{\text {int }} \mathrm{CD} 16^{+}, \mathrm{CD} 14^{++} \mathrm{CD} 16^{-}$monocytes, and $\mathrm{CD} 1 \mathrm{c}^{+}$dendritic cells correlated positively with type I interferon (IFN-I) activity detected in blood. In SLE patients treated with corticosteroids, Mer expression on monocytes correlated with prednisone dose, CD1 $\mathrm{c}^{+}$myeloid dendritic cells in patients treated with prednisone had higher levels of Mer expression than those in patients not receiving prednisone.
\end{abstract}

Conclusions: We found no global defect in Mer expression in lupus blood. In contrast, we observed increased levels of Mer expression in DC populations, which could represent a response to increased IFN-I in SLE patients. Enhanced Mer expression induced by corticosteroids may contribute to its beneficial effects in SLE.

\section{Introduction}

The Tyro3, Axl, and Mer receptors (TAMRs) comprise a family of receptor tyrosine kinases [1]. They are involved in the process of apoptotic debris recognition and removal in normal animals $[2,3]$. Their extracellular domains contain two N-terminal immunoglobulin-like domains that

\footnotetext{
* Correspondence: philco@temple.edu

'Section of Rheumatology, Department of Medicine, Temple University School of Medicine, 3322 North Broad Street, Philadelphia, PA 19140, USA ${ }^{2}$ Temple Autoimmunity Center, Temple University School of Medicine, 3500 North Broad Street, Philadelphia, PA 19140, USA

Full list of author information is available at the end of the article
}

are essential for binding the C-terminal part of their ligands, protein $\mathrm{S}$ and Gas6. These two ligands have similar protein-domain structure. The $\mathrm{N}$-terminal Gla domain of the ligands can bind the phosphatidyl serine on the surface of apoptotic cells, whereas two Cterminal laminin G-type receptor domains, comprising a sex hormone-binding globulin domain, can bind TAMR expressed on the surface of phagocytic cells. Activation of TAMR by Gas6 or protein $S$ on the surface of apoptotic debris facilitates phagocytosis of the apoptotic debris and triggers an associated suppression of proinflammatory 
cytokine production [4-9]. Thus, Mer may have a role in controlling immune responses to antigens exposed on apoptotic cells.

In gene-expression studies, Mer (named for its expression in monocytes, endothelium, and the reproductive system) is the most highly expressed of the TAMR in the immune system, whereas Axl is expressed at lower levels in monocytes [10] and also can be expressed in dendritic cells $[9,11,12]$. Tyro3, conversely, is widely expressed in the central nervous system, with little expression in the immune system [1]. In human peripheral blood, little information exists about constitutive TAMR expression. Mer is expressed in a population of pulmonary macrophages isolated from bronchoalveolar lavage, and its expression is increased in smokers [13] Mer expression is also increased on monocytes and neutrophils in patients with septic shock [14].

In mice, the TAMRs are implicated in the phagocytosis of apoptotic debris in the retina, the testis, and the hematopoietic and immune systems [2]. Activation of Mer provokes changes in the cytoskeleton of phagocytes, leading to the ingestion of apoptotic debris [15]. Mer deficiency results in a defective ability to remove apoptotic cells [3], which leads to a buildup of apoptotic debris. This accumulation of apoptotic cells and debris may stimulate autoreactivity [16].

Importantly, Mer expressed in DCs is an important factor in maintaining peripheral tolerance [7]. Mer deficiency could thus contribute to lack of tolerogenic dendritic cells and to excess apoptotic cell-derived antigen presentation.

A cardinal feature of human systemic lupus erythematosus (SLE) is the presence of autoantibodies against nuclear antigens. Because humans with SLE have been found to have defective clearance of apoptotic cells [17-20], it has been proposed that the nuclear antigens contained in such debris may serve as immunogens for anti-nuclear antibody immune responses [21].

Because clearance of apoptotic debris is impaired in SLE, we wondered whether TAMR expression might be diminished in this disorder. In SLE, perturbations in the levels of TAMR ligands Gas6 and protein $S$ and soluble TAMR are associated with disease activity [22-25], indicating that TAMR may be involved in disease progression. To examine the hypothesis that TAMRs are deficient in patients with lupus, we first tested and identified antibodies that could reliably detect TAMR. We were able to identify antibodies that could reliably detect Mer and Tyro3; however, we were unable to find an antibody that could specifically recognize Axl. We used flow cytometry to examine the expression of Mer and Tyro3 on peripheral blood leukocytes. We found that Mer was expressed on human monocytes, especially on the $\mathrm{CD} 14^{++} \mathrm{CD} 16^{+}$subpopulation, and also on $\mathrm{CD} 1 \mathrm{c}^{+}$ myeloid DCs, and at lesser levels on pDCs. When myeloid and plasmacytoid dendritic cells from SLE patients were compared with those from normal healthy subjects, we found that expression of Mer was significantly increased in lupus patients compared with normal subjects. This increase in expression could result from inflammatory stimulation, and indeed, Mer expression correlated with IFN-I activity in patient plasma.

\section{Materials and methods}

\section{Subject recruitment}

Patients and healthy controls consented to donate blood in accordance with a protocol approved by the Temple University Institutional Review Board. Normal subjects were recruited from students and workers at the Temple Health Sciences Campus. Only healthy subjects reporting no chronic illness or acute infections were recruited. SLE patients were from the Rheumatology Clinic at Temple University Hospital. Patients were diagnosed with lupus and fulfilled at least four American College of Rheumatology criteria (1997 Revision). The research protocol and consent forms were approved by the Temple University Institutional Review Board.

\section{Flow cytometry}

After informed consent was obtained, venous blood was drawn from patients and normal subjects into EDTAcontaining vacutainers (Becton Dickinson, Franklin Lakes, NJ). Peripheral blood mononuclear cells (PBMCs) were purified from blood by using Ficoll/Hypaque sedimentation to remove red blood cells and granulocytes. Then $0.5 \times 10^{6}$ cells were stained with fluorescent antibodies for analysis with flow cytometry. Antibodies used in the study and specific for Mer (clone 125518) and Tyro 3 (clone 96201) were obtained from R\&D (Minneapolis, MN, USA); Anti-CD1c (clone L161), -CD11c (clone BU15), -CD14 (clone M5E2), -CD42b (clone HIP1), -CD56 (clone HCD56), -CD 123 (clone 6H6), and -FcERI (clone AER-37) were obtained from Biolegend, San Diego, CA, USA; Anti-CD4 (clone RPA-T4) was obtained from eBiosciences (San Diego, CA, USA), and Anti-CD3 (clone UCHT1), -CD16 (clone 3G8), -CD19 (clone SJ25C1), and -HLA-DR (clone G46-6), were obtained from BD Biosciences, San Jose, CA, USA.

PBMCs were blocked by using a mixture of normal IgG from human and goat (1 mg each per tube). Antibody panels were added, and the cells were incubated on ice. Cells were washed and fixed in 1\% paraformaldehyde for 10 minutes, and washed and resuspended in PBS for analysis. Leukocyte subpopulations were defined by using antibodies to CD3, CD14, CD19, and CD56 to delineate $\mathrm{T}$ cells, monocytes, and $\mathrm{B}$ and NK cells, respectively. Anti-CD42b was used to exclude leukocyte-platelet aggregates, which are reported to express TAMR. Flow- 
cytometric data were collected on an LSRII flow cytometer (Becton Dickinson, Franklin Lakes, NJ, USA) and analyzed by using FlowJo software (Treestar, Ashland, OR, USA). To define subpopulations of monocytes, we used a five-color strategy including anti-CD16 (clone 3G8, BD Biosciences), anti-CD14, and anti-MHC II to identify subsets of monocytes, and collected the data on a FACSCanto flow cytometer (Becton-Dickinson). To define dendritic cells, we used a six-color strategy with anti-CD1c, -CD3, -CD19, -CD123, -HLADR, in addition to anti-Mer to identify $\mathrm{CD} 1 \mathrm{c}^{+}$myeloid DCs, the majority of myeloid dendritic cells. We used antibody-coated beads to compensate the data; however, we found that the plasmacytoid dendritic cells CD123-PE.Cy7 ${ }^{+}$gave values for $\mathrm{PE}$ (Mer) in the negative range by using this compensation; therefore, we used manual compensation PE-Cy7-PE to adjust the $\mathrm{PE}-\mathrm{Cy} 7^{\text {hi }}$ cell population to match the $\mathrm{PE}$ fluorescence values of the PE-Cy7-negative cells in a cell sample that contained no Mer-labeled antibody.

\section{sMer ELISA}

The total Mer ELISA kit duoset from R\&D was used to quantify Mer in plasmas from lupus patients and normal controls. Conventional methods were used to carry out the ELISA. The monoclonal capture antibody at a concentration of $1.6 \mu \mathrm{g} / \mathrm{ml}$ was used to coat high-binding 96-well plates. Plates were blocked with 1\% BSA. Plasmas were diluted 1:4 in PBS containing 1\% BSA for use in the assay. The polyclonal biotinylated detection antibody was used at a concentration of $200 \mathrm{ng} / \mathrm{ml}$. Horseradish peroxidase conjugated to streptavidin (R\&D) was used with TMB substrate to detect the antigen. The ELISA could detect the extracellular portion of Mer in a Mer-Human Fc fusion protein.

\section{Interferon type 1 (IFN-I) activity assay}

This assay measures IFN-I activity by using an interferon-sensitive reporter element linked to an alkaline phosphatase gene. Hek Blue ISRE-SEAP cells (InvivoGen, San Diego, CA, USA) were plated at 50,000 cells per well in $200 \mu \mathrm{l}$ media and incubated overnight at $37^{\circ} \mathrm{C}$. The next day, supernatants were removed from cells and replaced with $100 \mu \mathrm{l}$ of a $50 \%$ plasma/media dilution. Cells were incubated overnight with plasma at $37^{\circ} \mathrm{C}$. Next day, $40 \mu \mathrm{l}$ of supernatant from every well was added to $160 \mu \mathrm{l}$ of AP substrate and allowed to incubate for 20 minutes. The plate was read at $650-\mathrm{nm}$ absorbance by using a spectrophotometer.

\section{Statistics}

The Welch $t$ test was used for statistical comparison of TAMRs between SLE patients and normal controls for data that showed gaussian distribution and unequal variances. Spearman Rank correlation test was used with data that showed non-gaussian distribution. Graphpad Prism (GraphPad Software, Inc., La Jolla, CA) was used for the comparison and correlative analyses. For all tests, significance was defined as $P<0.05$.

\section{SLE disease activity index (SLEDAI) estimation}

The SLEDAI Selena modification was used for scoring [26]. The score was estimated by examining the patient chart and the doctor's comments of the day of the patient blood draw. The patient was considered to be antidouble-stranded DNA positive on the day of the visit if the patient had positive serology in the past.

\section{Results}

We recruited a total of 48 lupus patients and 35 healthy individuals for our study. These subjects were used in two groups. The first cohort was used to study the expression of Mer and Tyro3 in leukocyte subpopulations (Group 1), and the second, to study the expression of Mer on monocyte subsets and dendritic cell subsets (Group 2). The clinical characteristics of the groups are given in Table 1. It should be noted that the control and lupus cohorts are not well matched for gender and

Table 1 Healthy normal and SLE patient characteristics

\begin{tabular}{|c|c|c|c|c|}
\hline \multirow[b]{2}{*}{ Demographic } & \multicolumn{2}{|c|}{ Group 1} & \multicolumn{2}{|c|}{ Group 2} \\
\hline & Lupus & Normal & Lupus & Normal \\
\hline Age (years) & $37.87 \pm 10.23$ & $38.41 \pm 13.82$ & $46.1 \pm 14.0$ & $40.5 \pm 12.4$ \\
\hline Sex F:M & $21: 1$ & $5: 9$ & $26: 3$ & $8: 7$ \\
\hline \multicolumn{5}{|l|}{ Ethnicity } \\
\hline $\begin{array}{l}\text { African- } \\
\text { American }\end{array}$ & 15 & 3 & 19 & 7 \\
\hline Hispanic & 7 & 0 & 5 & 0 \\
\hline Caucasian & 0 & 11 & 6 & 5 \\
\hline Asian & 0 & 0 & 0 & 4 \\
\hline \multicolumn{5}{|l|}{ Parameter } \\
\hline Anti-dsDNA & $10 / 22$ & & $18 / 29$ & \\
\hline Anti-Sm & $8 / 22$ & & $16 / 29$ & \\
\hline Anti-Ro & $6 / 22$ & & $12 / 29$ & \\
\hline Anti-La & $2 / 22$ & & $1 / 29$ & \\
\hline Anti-cardiolipin & $6 / 22$ & & $5 / 29$ & \\
\hline $\begin{array}{l}\text { Lupus } \\
\text { anticoagulant }\end{array}$ & $2 / 22$ & & $5 / 29$ & \\
\hline $\begin{array}{l}\text { Anti-B } \\
\text { glycoprotein I }\end{array}$ & $1 / 22$ & & $6 / 29$ & \\
\hline $\begin{array}{l}\text { Anti- } \\
\text { phospholipid }\end{array}$ & $3 / 22$ & & $3 / 29$ & \\
\hline C3 low $(<90)$ & $6 / 22$ & & $7 / 29$ & \\
\hline C4 low $(<16)$ & $5 / 22$ & & $8 / 29$ & \\
\hline $\begin{array}{l}\text { SLEDAI mean } \pm \\
\text { StDev }\end{array}$ & $3.17 \pm 3.13$ & & $5.6 \pm 3.4$ & \\
\hline
\end{tabular}


ethnicity. We examined the effect of gender on the expression of Mer, and the results are described later.

\section{Expression of TAMRs on peripheral blood mononuclear cells of normal individuals}

In initial experiments, phycoerythrin-conjugated antiMer and anti-Tyro3 antibodies were identified that gave positive staining on tumor cell lines known to express Mer (THP-1) and Tyro3 (K562) (see Additional file 1: Figure S1). With these antibodies, we examined the expression of the TAMR on human peripheral blood cells with multicolor flow cytometry. We included in our panel of antibodies monoclonal antibodies to recognize $\mathrm{B}$ (CD19), T (CD3), and natural killer (CD56) lymphocytes, and monocytes (CD14). These antibodies were used in combination to identify T, B, NK cells, monocytes with high CD14 expression, and cells expressing intermediate levels of CD14. Subset population discrimination is shown in Figure 1A. The relative levels of expression of Mer and Tyro3 on the leukocyte subsets were examined by using anti-Mer and anti-Tyro3 monoclonal antibodies. Highest expression of Mer was observed on monocytes, with minimal expression on lymphocytes. (Figure 1B; Additional file 1: Figure S2). We examined one normal subject at two different time points and another normal subject at three different time points, and observed some variation in expression over time (Figure 1C).

Our initial antibody panel was designed to examine the expression of Mer and Tyro3 on the major leukocyte subsets, and we did not attempt to examine the characterized subpopulations of monocytes present in peripheral blood [27]. We observed a subset of cells expressing intermediate levels of CD14 (14 ${ }^{\text {int }}$ in Figure 1A), and this population had higher levels of Mer compared with the monocytes expressing high levels of CD14 and myeloid dendritic cells. Because CD14 intermediate monocytes expressing CD16 are a distinct subset of monocytes with potentially important patrolling function in the vasculature [28], we wished to demonstrate that the $14^{\text {int }}$ population were monocytes and to look at Mer expression on the monocyte subsets. Therefore, we used another antibody panel on a second group of subjects (Group 2), by using antibodies specific for CD14, CD16, and MHC II to identify monocyte subsets (Figure 2). Interestingly, we found that within the monocyte subsets, Mer was expressed at highest levels on the population of monocytes expressing CD16 and high levels of CD14 $\left(\mathrm{CD} 14^{++} \mathrm{CD} 16^{+}\right)$monocytes [27], somewhat lower levels on the nonclassic monocytes expressing CD16, $\mathrm{CD} 14{ }^{\text {int }} \mathrm{CD} 16^{+}$population, and at lowest levels in the classic monocytes not expressing CD16 but expressing high levels of CD14 $\left(\mathrm{CD} 14^{++} \mathrm{CD} 16^{-}\right)$(Figure 2B, C). The classic monocytes comprise the majority of monocytes in the circulation.

We also examined the expression of Mer on dendritic cells in the second set of subjects by using another antibody panel. Dendritic cells were identified as illustrated in Figure 3A. CD1c dendritic cells comprise the largest population of myeloid dendritic cells in normal blood [27]. These cells were identified in the $\mathrm{HLADR}^{+} \mathrm{CD}^{-}$

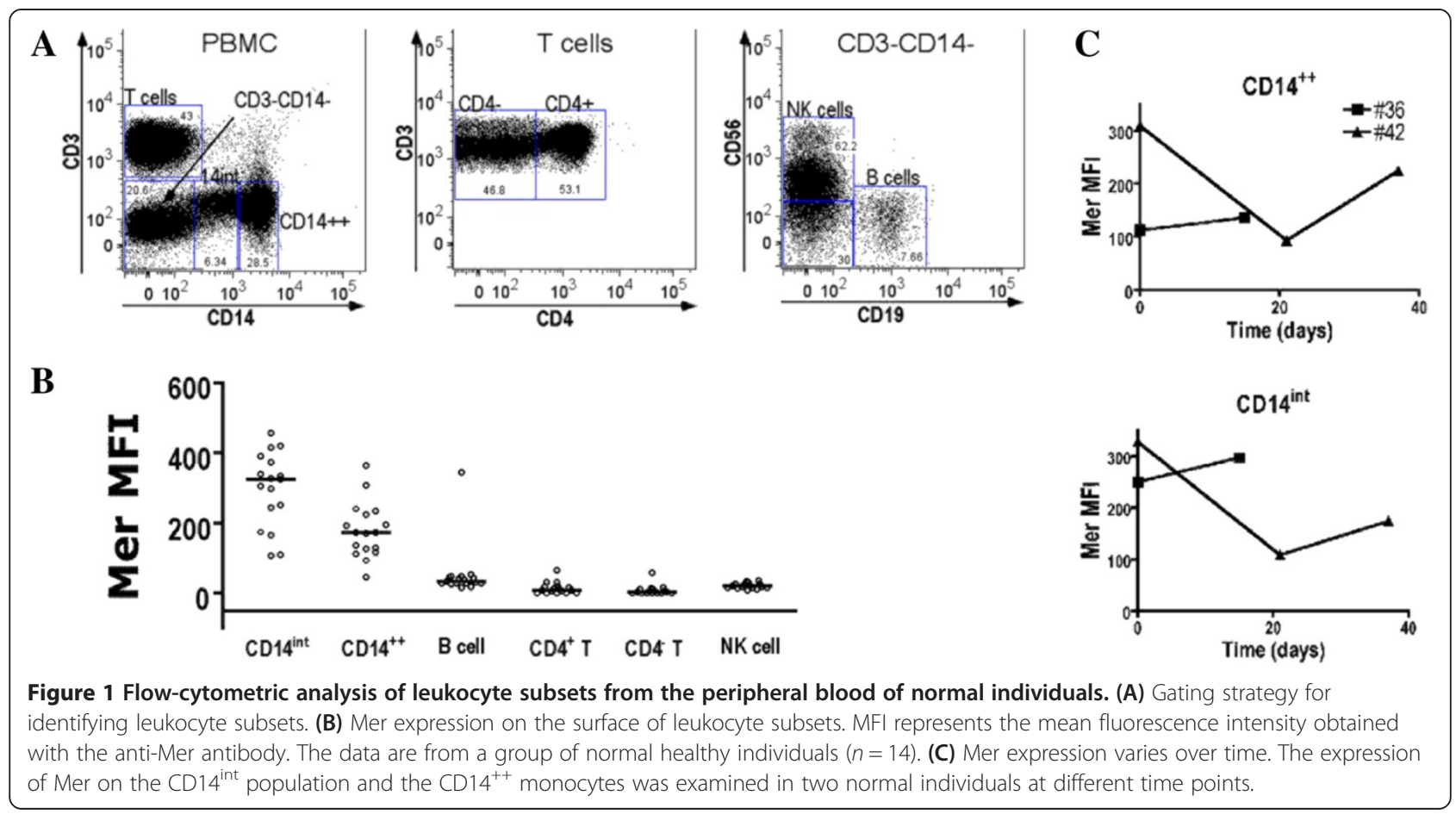



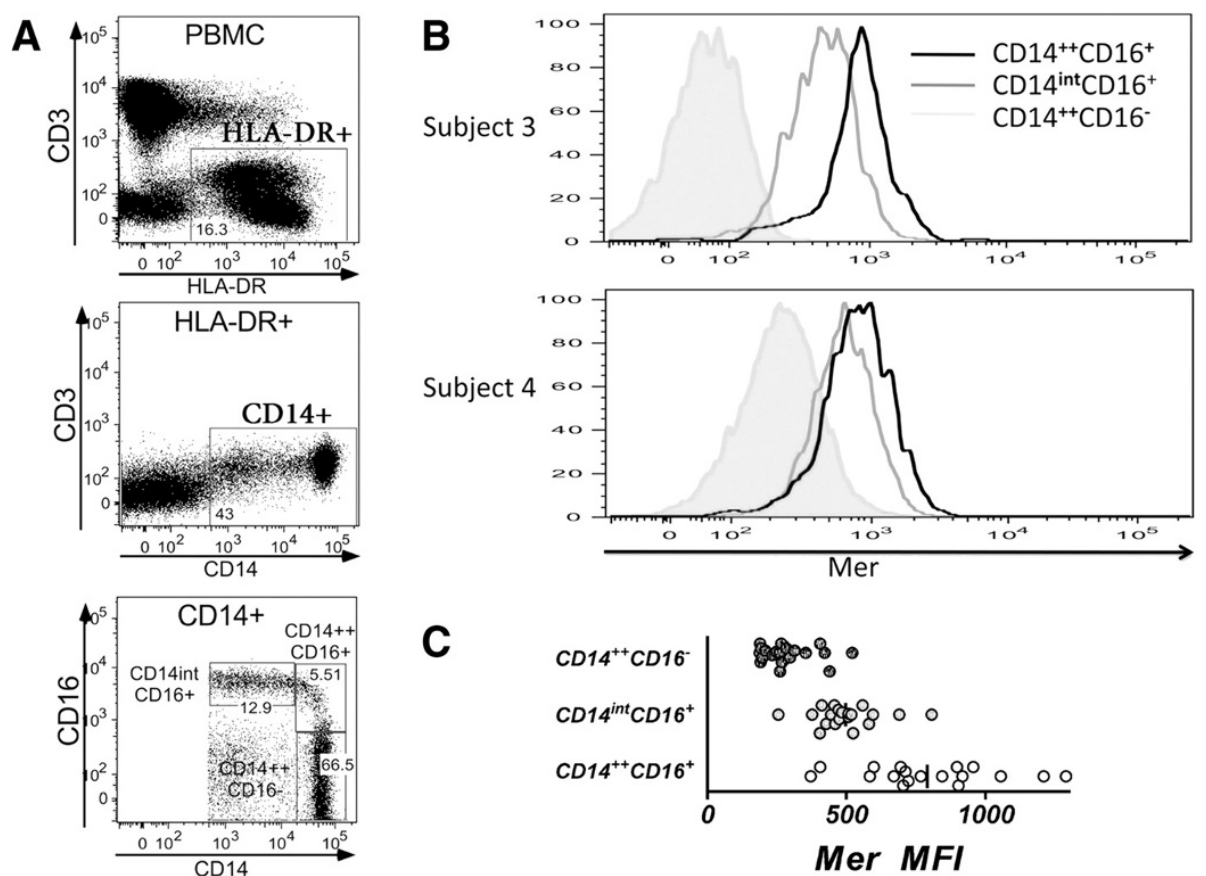

C

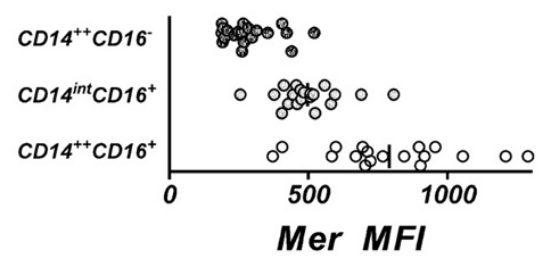

Figure 2 Expression of Mer on monocyte subpopulations from the peripheral blood of normal individuals. (A) Gating strategy for the identification of monocyte subsets. (B) Expression of Mer on the surface of monocyte subpopulations from the peripheral blood of two representative normal individuals. (C) Mean expression of Mer on monocyte subsets of normal individuals $(n=20)$.

population of cells. CD1c ${ }^{+} \mathrm{B}$ cells were excluded by using CD19. Plasmacytoid dendritic cells were identified as $\mathrm{HLADR}^{+} \mathrm{CD}^{-}{ }^{-} \mathrm{CD} 123^{\text {hi }}$ cells. We observed Mer expression on the surface of both $\mathrm{CD} 1 \mathrm{c}^{+}$myeloid DCs (mDCs) and on the surface of plasmacytoid dendritic cells (pDCs). Levels of Mer were higher on the surface of $\mathrm{CD} 1 \mathrm{c}^{+} \mathrm{mDCs}$ than on the surface of pDCs (Figure 3B through D).

\section{Expression of TAMR on peripheral blood mononuclear cells from SLE patients}

When we compared SLE patients with normal controls, we found no difference in expression of Mer on CD14 ${ }^{+}$ monocyte populations in either of the two groups of subjects we tested (Figure 4A, B). Mer expression in monocytes from lupus patient blood followed the same pattern as in monocytes from healthy individuals, with highest expression in the $\mathrm{CD} 14^{++} \mathrm{CD} 16^{+}$populations and lowest in the $\mathrm{CD} 14^{++} \mathrm{CD} 16^{-}$populations. In $\mathrm{CD} 14^{++} \mathrm{CD} 16^{+}$monocytes, Mer expression levels were lower in SLE compared with normal, although full statistical significance was not reached (Figure 4B). A statistically significant increase in the levels of Mer expression compared with normal subjects was observed on SLE dendritic cells.

Among DCs, a significant increase in the levels of Mer expression was found in both pDCs and in $\mathrm{CD} 1 \mathrm{c}^{+}$myeloid DCs from lupus patients compared with healthy control subjects (Figure 4C). The lupus myeloid DC data included one high-expression outlier; however, even if that data point were excluded from the analysis, the difference remained significant. Because the function of Mer expressed on the surface of peripheral blood leukocytes can be suppressed by the presence of sMer in the blood [29], we examined the levels of sMer in plasma samples from the normal and lupus patients. In agreement with earlier studies [23,25], increased levels of sMer were present in the blood of lupus patients compared with normal healthy individuals (Figure 4D).

Mer is generally not thought to be expressed on lymphocytes, and we found only minimal levels in our patients, yet clearly above background. When T-cell expression was examined more closely, an increase in Mer expression was found on $\mathrm{CD} 4^{+}$but not $\mathrm{CD} 4^{-} \mathrm{T}$ cells in lupus patients compared with the normal control subjects (Additional file 1: Figure S2A). The significance of this increase is uncertain.

Because our control group was not gender-matched to the predominantly female SLE patient group, we wondered whether male-female differences alone might influence Mer levels. Accordingly, we narrowed the control group to include only female subjects. Although no significant differences were found between Mer expression on monocyte subsets between lupus patients and normal healthy individuals (Additional file 1: Figure $\mathrm{S} 3 \mathrm{~A})$, the increases in Mer expression on $\mathrm{CD}_{1} \mathrm{c}^{+}$and pDCs in lupus patients was preserved (Additional file 1: 


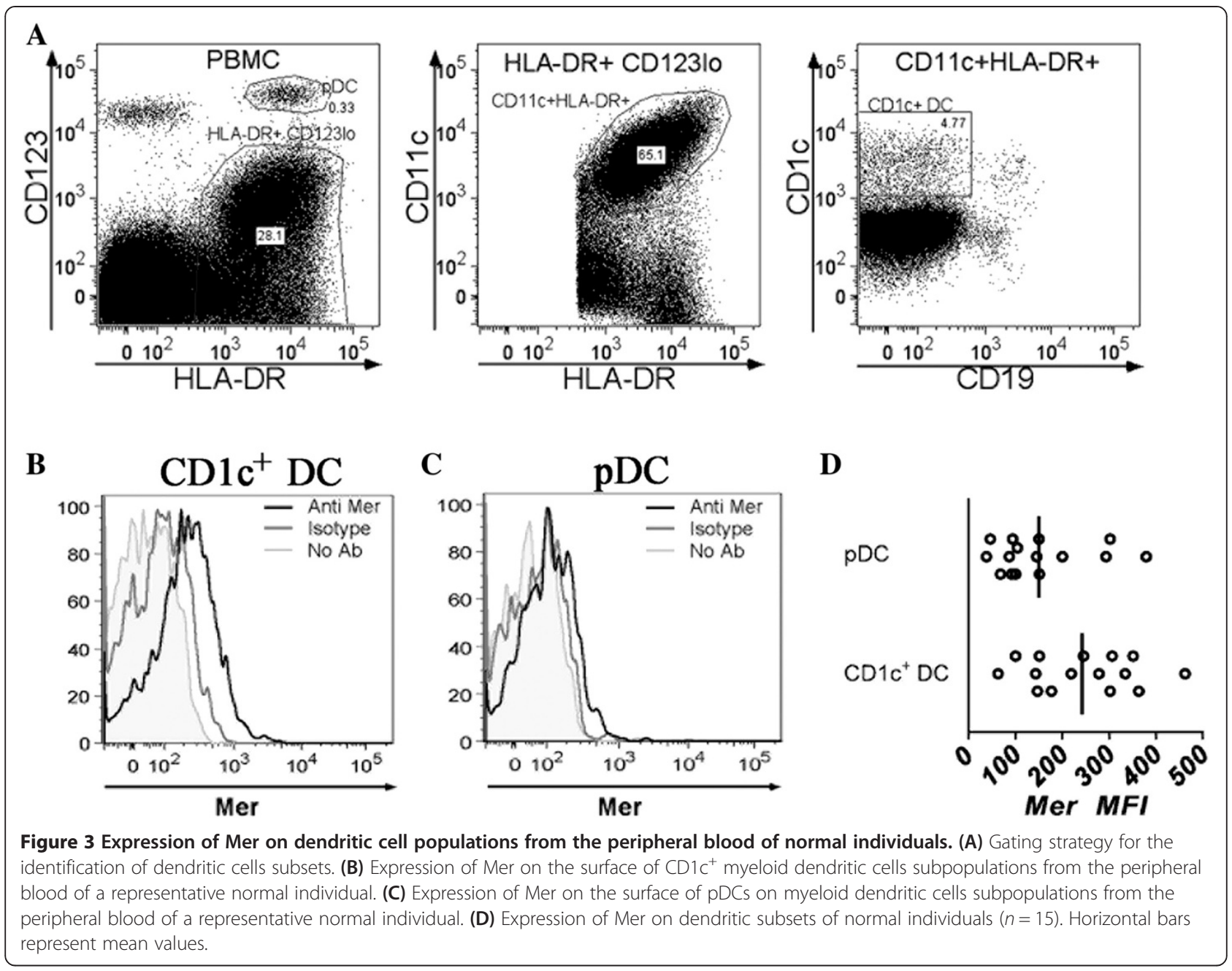

Figure S3B). We compared the levels of Mer expressed on the monocytes and DC from female and male subjects within our control group. We did observe somewhat higher levels of Mer on the $\mathrm{CD} 14^{++} \mathrm{CD} 16^{+}$ monocyte subset in normal females compared with the SLE group (Additional file 1: Figure S3C). Also in both $\mathrm{CD}_{1} \mathrm{c}^{+}$myeloid DC and pDC populations, Mer expression was higher in healthy men compared with healthy women (Additional file 1: Figure S3D), yet the differences failed to reach statistical significance. Thus, it is unlikely that sex differences accounted for our findings.

The possibility that racial differences were important, however, is real and will require further investigation.

Because type I interferon can activate expression of TAMR in vitro $[9,11]$, and because interferon levels are related to active disease in SLE patients [30], we hypothesized that the levels of Mer might be influenced by the levels of interferon in the blood of patients with SLE. We tested the plasma of lupus patients from the same blood samples used for the flow-cytometry test for Mer expression. We used an interferon type I reporter assay with the interferon-stimulated response element that is activated by the interferon-stimulated gene factor 3 complex pathway of activation by IFN-I. We observed IFN-I activity levels above background in many of the lupus patient samples, yet in none of the normal controls (Figure $5 \mathrm{~A}$ ). Interferon activity was positively associated with Mer expression on $\mathrm{CD} 14^{\text {int }} \mathrm{CD} 16^{+}$and $\mathrm{CD} 1 \mathrm{c}^{+}$myeloid dendritic cells (Figure 5B and $\mathrm{C}$ ). Interestingly, interferon activity levels were also negatively associated with the proportion of the $\mathrm{CD} 144^{\text {int }} \mathrm{CD} 16^{+}$monocyte subset and the $\mathrm{CD} 1 \mathrm{c}^{+} \mathrm{DCs}$ and positively with the proportion of the $\mathrm{CD} 14^{++} \mathrm{CD} 16^{+}$monocyte subset (Figure 5D through F).

We also examined associations between levels of Mer expression on the monocyte subsets and myeloid DC with various clinical parameters. Mer expression did not correlate with organ involvement, autoantibody, age, or SLEDAI score. Interestingly, the levels of Mer on the monocyte subsets in SLE patients who were being treated with prednisone were positively correlated with dose (Figure 6A). No significant difference was found in the levels of Mer expression on monocytes from those 


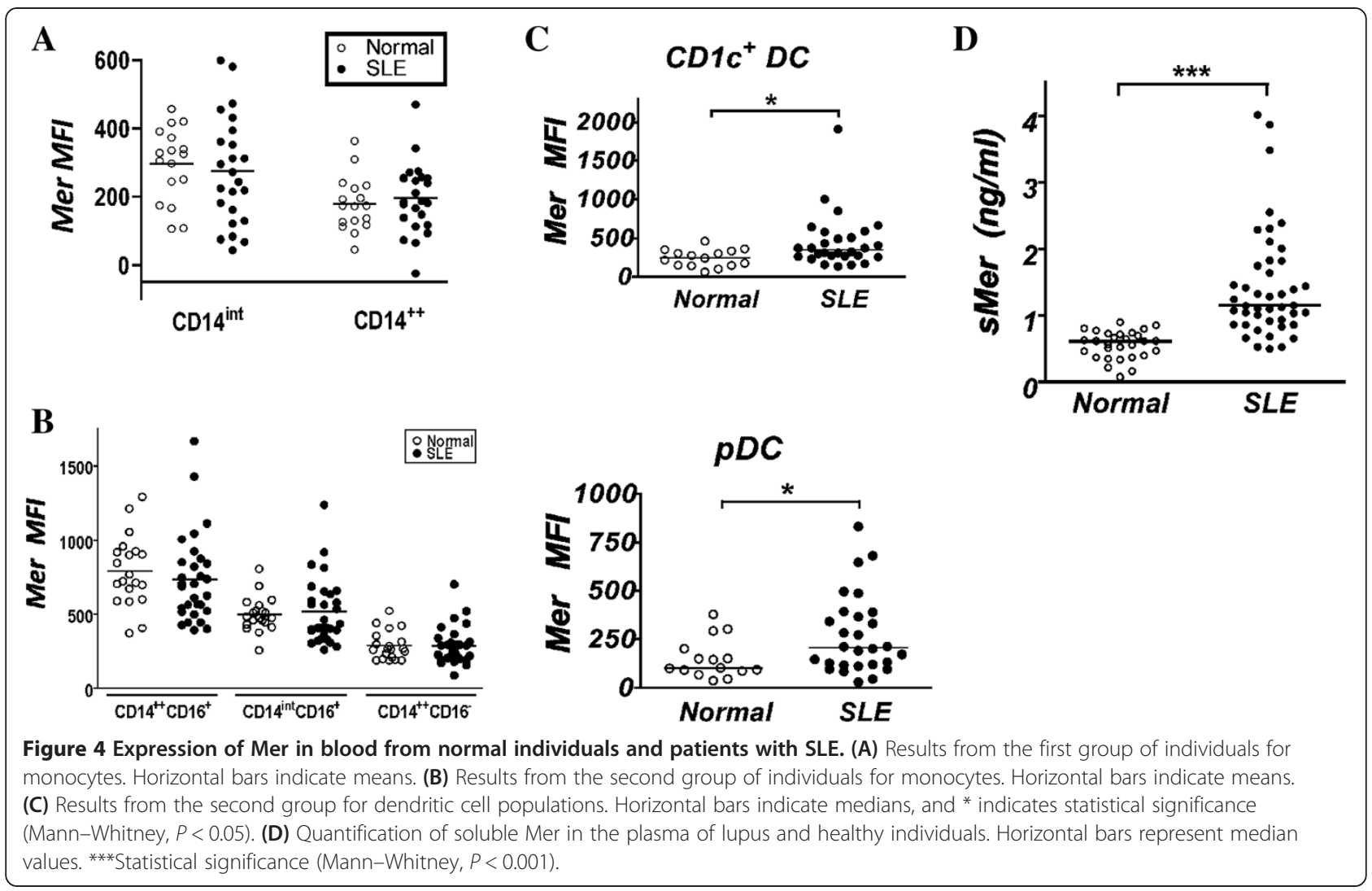

patients receiving prednisone compared with those not receiving prednisone or normal healthy control subjects (Figure 6B). However, $\mathrm{CD}_{1} \mathrm{c}^{+}$myeloid dendritic cells in patients receiving prednisone had higher levels of Mer expression than did those in patients not receiving prednisone (Figure 6C). Levels of Mer expression on CD1c $\mathrm{c}^{+}$ DC appeared to be higher in patients not treated with prednisone compared with normal healthy individuals; however, this difference just failed to reach significance $(P=0.0729)$

Of note, the Mer levels on the three monocyte subsets were highly correlated with each other and also with Mer levels on the CD1c ${ }^{+}$DC population (Figure 7). The levels of Mer expression on the $\mathrm{CD} 14{ }^{\text {int }} \mathrm{CD} 16^{+}$subpopulation were negatively correlated with their proportion, with the proportion of the $\mathrm{CD} 14^{++} \mathrm{CD} 16^{+}$subpopulation, and also with the proportion of both $\mathrm{CD} 1 \mathrm{c}^{+} \mathrm{mDC}$ and pDCs found in the blood (Figure 8). These data suggest that Mer expression on monocytes and DCs is related to their total numbers and thus to the magnitude of ongoing inflammation.

We also found a strong correlation between the levels of Mer on the $\mathrm{CD} 1 \mathrm{c}^{+} \mathrm{mDCs}$ with the proportion of pDCs in the blood (Figure 9A). Additionally, the proportions of both $\mathrm{CD} 1 \mathrm{c}^{+} \mathrm{DCs}$ and the $\mathrm{pDCs}$ were reduced in the SLE group compared with the normal healthy control group (Additional file 1: Figure S4).
We did not find a correlation between the levels of sMer with membrane-bound Mer on the surface of any cell type examined. However, sMer levels were negatively correlated with the numbers of neutrophils in the blood of lupus patients (Figure 9B).

Because prednisone treatment influences the levels of Mer on peripheral blood monocytes and dendritic cells, we looked at the subgroup of patients not receiving prednisone (Additional file 1: Figure S5). Notwithstanding the lower number of data points, we observed additional positive correlates of IFN-I activity with Mer expression on $\mathrm{CD} 14^{++} \mathrm{CD} 16^{+}$monocyte populations and also notably with sMer. Increased strength of correlation (Spearman $r$ ) of IFN-I activity was noted, positively to the expression of Mer on the $\mathrm{CD} 14{ }^{\text {int }} \mathrm{CD} 16^{+}$subgroup of monocytes, and negatively to the proportion of this monocyte subpopulation present in peripheral blood. An increased strength of positive correlation of IFN-I activity also was noted with the proportion of $\mathrm{CD} 14^{++} \mathrm{CD} 16^{+}$ monocyte subpopulation,

As expected, Tyro3 was generally expressed at low levels in leukocyte subsets in peripheral blood. However, in some normal individuals and some SLE patients, Tyro3 was expressed above background levels in the CD14 ${ }^{\text {int }}$ cells and B-cell populations (Additional file 1: Figure S2A). Surprisingly, a small but significant increase in Tyro3 expression was present on $\mathrm{CD} 4^{+} \mathrm{T}$ cells in 


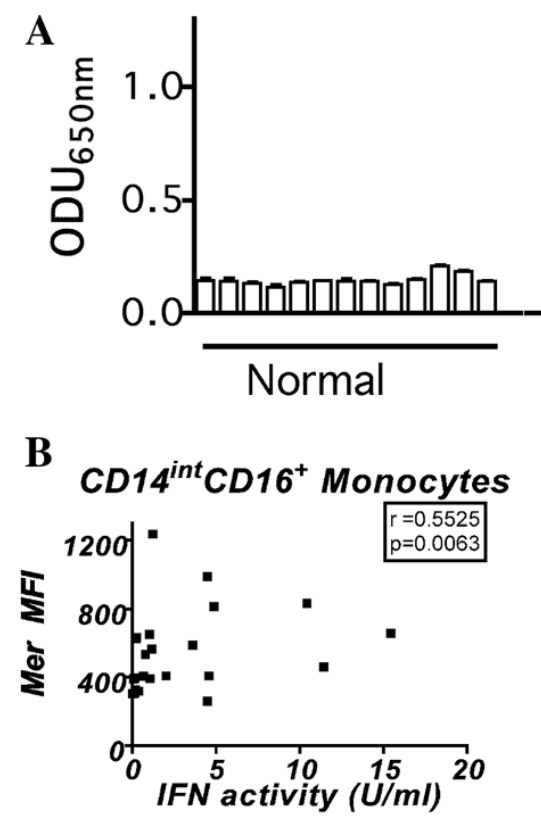

D

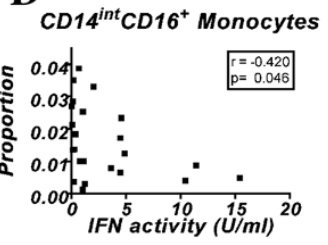

$\mathbf{E}$

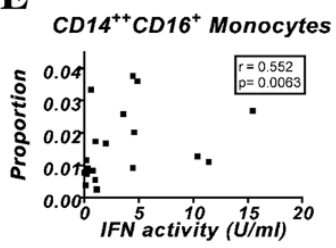

$\mathbf{C}$

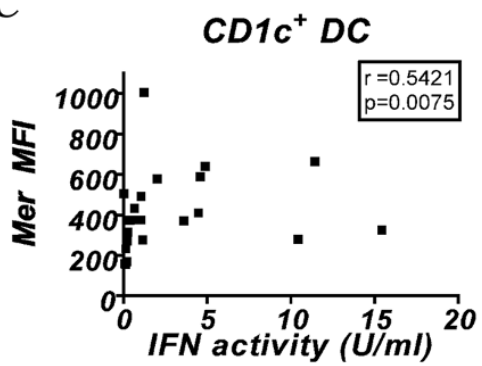

$\mathbf{F}$

Figure 5 Expression of Mer on monocytes and myeloid dendritic cells in patients with SLE correlates with IFN-I activity. Interferon activity influences the proportion of monocytes and myeloid dendritic cells in blood. (A) IFN-I activity in plasmas from normal individuals and SLE patients. The optical density units obtained for plasma-induced alkaline phosphatase activity in plasmas are shown. Mer levels on (B) CD14 ${ }^{\text {int }}$ CD $16^{+}$ monocyte and (C) CD14 ${ }^{++} \mathrm{CD} 16^{-}$and CD1 $\mathrm{C}^{+} \mathrm{DC}$ subsets positively correlate with IFN-I activity. The proportions of (D) $\mathrm{CD} 14^{\text {int }} \mathrm{CD} 16^{+}$monocytes, (E) $\mathrm{CD} 14^{++} \mathrm{CD} 16^{-}$monocytes, and (F) CD1 $\mathrm{C}^{+}$myeloid dendritic cell subsets negatively correlate with IFN-I activity. Spearman rank correlation was used to determine significance. Values for Spearman $r$ and $P$ values are given for the different correlates.

lupus patients. The expression of Tyro3 was strongly associated with the expression of Mer in the $\mathrm{CD}_{4}^{+} \mathrm{T}$ lymphocytes of lupus patients (Figure 9C).

\section{Discussion}

The present findings establish that Mer is expressed primarily on monocytes and dendritic cells in humans. Contrary to our expectations, we did not find reduced Mer expression on blood mononuclear cells from SLE patients. In contrast, the expression of Mer in certain monocytes and myeloid dendritic cells was increased, and this correlated with type I interferon levels. The cell distribution of human Mer expression parallels our findings of Mer expression in the mouse [31,32]. Normal human monocytes expressed significant levels of Mer overall, and expression was higher on $\mathrm{CD} 16^{+}$monocytes, especially the $\mathrm{CD} 14^{++} \mathrm{CD} 16^{+}$subset of monocytes, with lower levels on the $\mathrm{CD} 14^{++} \mathrm{CD} 16^{-}$subset. Mer expression is greatly increased in human macrophages matured in vitro [33], and specifically those differentiated along the M2 lineage [34]. The relatively low levels of Mer observed in human peripheral blood monocytes are therefore probably reflective of their relatively undifferentiated state.

Compelling evidence suggests that the three monocyte populations represent a continuous line of development in the circulation, with the $\mathrm{CD} 14^{++} \mathrm{CD} 16^{+}$population representing a transitional phase between the least-advanced classic $\mathrm{CD} 14^{++} \mathrm{CD} 16^{-}$monocytes and the most-mature $\mathrm{CD} 14^{\text {int }} \mathrm{CD} 16^{+}$monocytes [35], with some characteristics of tissue macrophages [36].

However, functional differences exist between monocytes segregated into the three populations. The $\mathrm{CD} 14^{++} \mathrm{CD} 16^{+}$ subset respond well to LPS, producing more TNF- $\alpha$ and IL-1 $\beta$ than the other monocyte subsets [28], but they also produce significant amounts of the antiinflammatory cytokine IL-10 [37]. Good evidence indicates that the $\mathrm{CD} 14^{++} \mathrm{CD} 16^{+}$monocytes can efficiently activate $\mathrm{T}$ cells, as they express high levels of MHC class II compared with the other subsets [38], and 


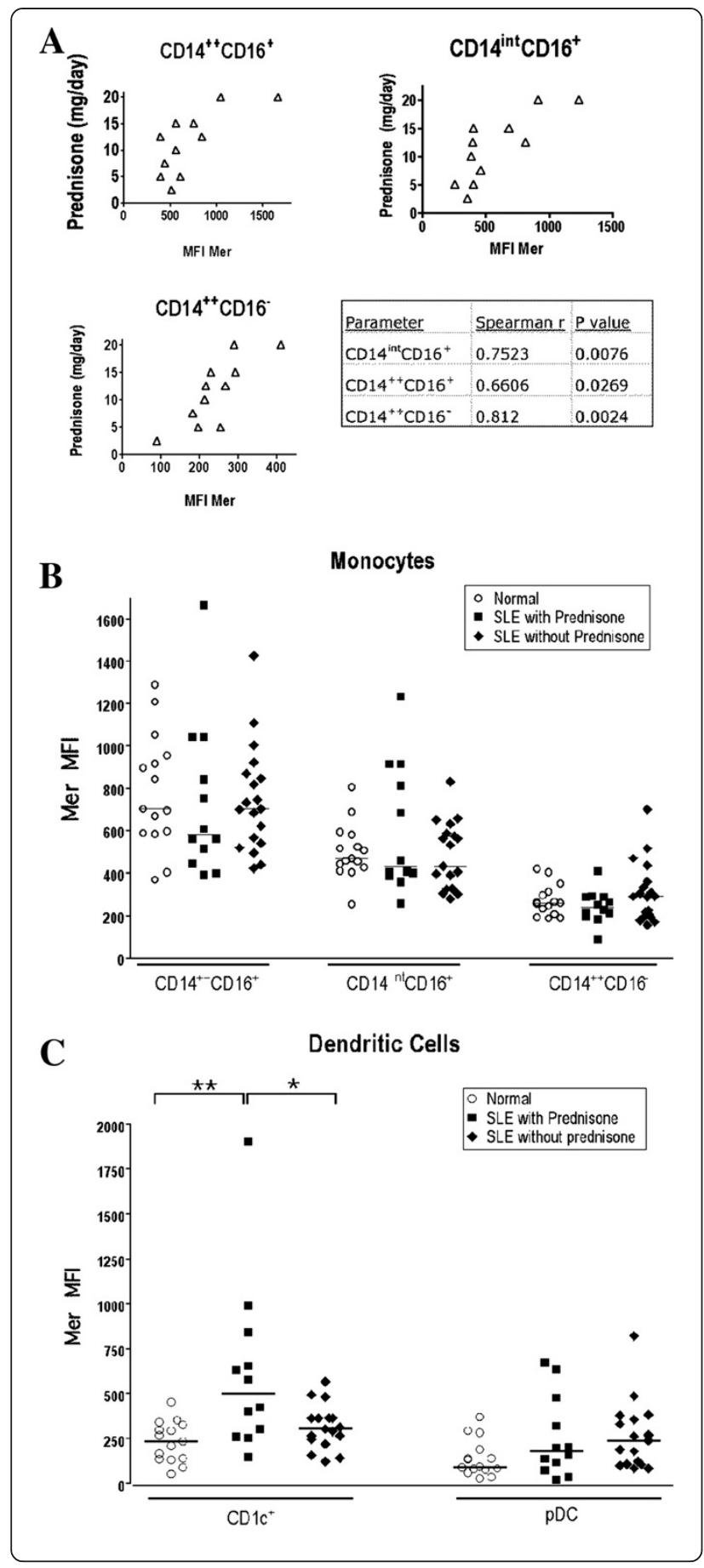

Figure 6 Prednisone dose correlates with Mer expression on all three monocyte subsets in patients with SLE receiving prednisone; and prednisone treatment increases Mer expression on myeloid dendritic cells. (A) Spearman rank correlation was used to determine the significance of correlation between Mer levels in patients receiving prednisone and dose levels of the prednisone. Values for Spearman $r$ and $P$ value are given for the different correlates in the Table. (B) Mer levels on monocytes were compared between normal healthy controls and SLE patients not treated and treated with prednisone. (C) Mer levels on dendritic cells were compared between normal healthy controls and SLE patients not treated and treated with prednisone. Significance was determined by using the Mann-Whitney rank correlation test. Horizontal bars indicate the median values for the groups. ${ }^{*} P<0.05 ;{ }^{* *} P<0.001$.

functionally were best at instigating a superantigeninduced T-cell response. Therefore, the higher expression of Mer on these cells suggests that it can play an important role in regulating apoptotic cell phagocytosis and any ensuing T-cell response. Based on the higher levels of Mer expression on $\mathrm{CD} 14^{++} \mathrm{CD} 16^{+}$monocytes, a role for Mer may exist in other diseases. The $\mathrm{CD} 14^{++} \mathrm{CD} 16^{+}$subset are expanded in patients with rheumatoid arthritis [39]. Increased numbers of the population predict the risk of cardiovascular disease in patients with chronic kidney disease [40], patients receiving hemodialysis [41], and patients selected for coronary angiography [42]. However, the expression profile of Mer in these conditions is not known.

In contrast to the $\mathrm{CD} 14^{++} \mathrm{CD} 16^{+}$subset, the $\mathrm{CD} 14^{\text {int }} \mathrm{CD} 16^{+}$ population of monocytes respond poorly to LPS but have an enhanced reaction to viruses and nucleic acids [28]. The human $\mathrm{CD} 14^{\text {int }} \mathrm{CD} 16^{+}$monocyte subset also have a unique patrolling function in the vasculature, as demonstrated by their ability to "crawl" on the endothelium of mouse blood vessels, [28]. It is tempting, therefore, to propose a role in vascular endothelial repair for these specialized monocytes because of the potential role of Mer in the recognition and removal of damaged endothelial and other component cells of the vasculature that express phosphatidyl serine on their surfaces.

The increased expression of Mer in the $\mathrm{CD}_{16}{ }^{+}$subsets of monocytes is consistent with a role for Mer in the phagocytosis of apoptotic cells, because among monocytes, the $\mathrm{CD} 16^{+}$monocytes preferentially phagocytose apoptotic cells [34]. The relatively high expression of Mer in the $\mathrm{CD} 16^{+}$cell subsets is also consistent with a role for Mer in the observed inhibition of TNF- $\alpha$ and IL-1 $\beta$ production in $\mathrm{CD} 16^{+}$monocytes by apoptotic neutrophils [43].

Our finding that circulating human myeloid DCs express Mer, parallels the expression of Mer on fresh splenic DCs in mice. Although Mer is not required for phagocytosis of apoptotic cells in mouse dendritic cells [31], with Axl and Tyro3 being more important for the 

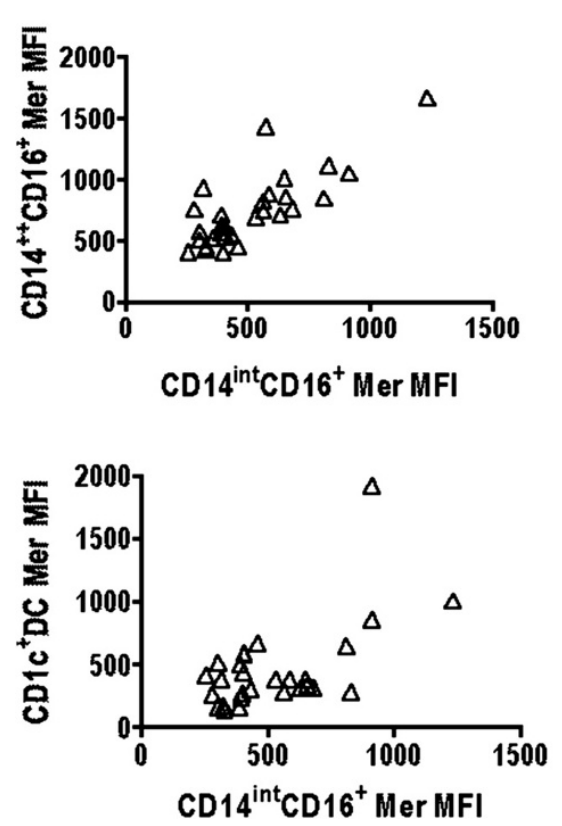

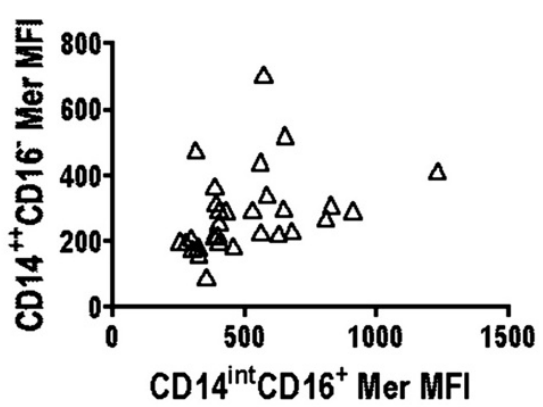

\begin{tabular}{|lcc|}
\hline \multicolumn{3}{|c|}{ Correlations with Mer levels on $\mathrm{CD} 14^{\mathrm{nt}} \mathrm{CD} 16^{+}$monocytes } \\
Parameter & Spearman $\mathrm{r}$ & Pvalue \\
$\mathrm{CD1} 4^{++} \mathrm{CD} 16^{+}$Mer & 0.716 & $<0.0001$ \\
$\mathrm{CD1} 4^{++} \mathrm{CD} 16-\mathrm{Mer}$ & 0.511 & 0.0033 \\
$\mathrm{CD1} \mathrm{c}^{+} \mathrm{DC}$ Mer & 0.460 & 0.014 \\
\hline
\end{tabular}

Figure 7 Levels of Mer on $\mathrm{CD} 14^{\text {int }} \mathrm{CD} 16^{+}$monocytes positively correlate with the levels of Mer in the other monocyte subgroups and on $\mathrm{CD}_{1 \mathbf{c}^{+}}$myeloid DCs. Spearman rank correlation was used to determine significance. Values for Spearman $r$ and $P$ value are presented for the different subsets in the table.

phagocytosis of apoptotic cells by mouse splenic and bone marrow-derived dendritic cells [12], Mer functions as an important regulator of DC activation in mice $[7,44]$. The loss of Mer in in vitro-generated mouse dendritic cells led to a lack of the regulation of NF-kB activation by apoptotic cells. In a mouse model of autoimmune diabetes, loss of Mer was associated with increased numbers of pancreatic DCs and an increased ability of DCs to stimulate islet-specific T cells [45]. Therefore, a lack of Mer-dependent DC regulation could
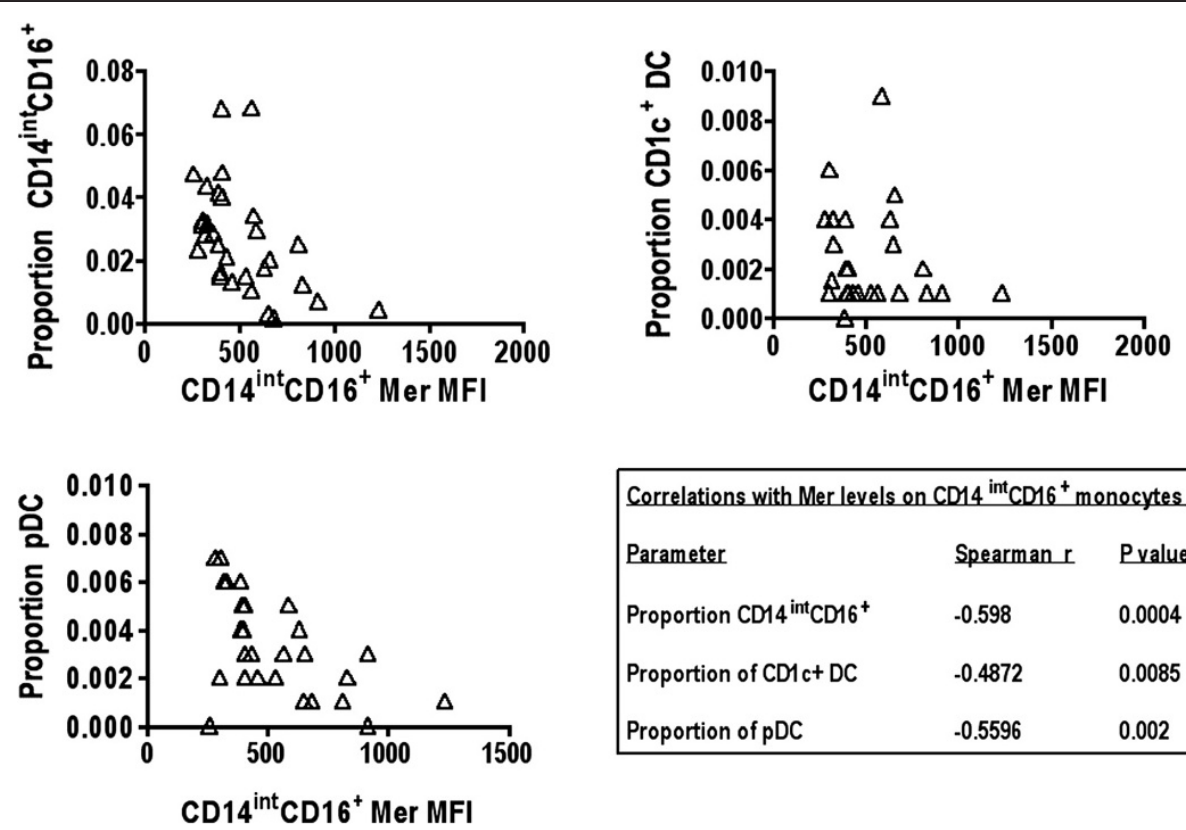

\begin{tabular}{|llr|}
\hline \multicolumn{3}{|l|}{ Correlations with Mer levels on $\mathrm{CD} 14^{\text {int }} \mathrm{CD} 16^{+}$monocytes } \\
Parameter & Spearman $\mathrm{r}$ & Pvalue \\
Proportion $\mathrm{CD} 14^{\mathrm{int}} \mathrm{CD} 16^{+}$ & -0.598 & 0.0004 \\
Proportion of CD1c+ DC & -0.4872 & 0.0085 \\
Proportion of $\mathrm{pDC}$ & -0.5596 & 0.002 \\
\hline
\end{tabular}

Figure 8 Levels of Mer on $\mathrm{CD} 14^{\text {int }} \mathrm{CD} 16^{+}$monocytes are negatively correlated with the proportion of $\mathrm{CD} 14^{\text {int }} \mathrm{CD} 16^{+}$monocytes, the proportion of $\mathrm{CD} 1 \mathrm{c}^{+}$dendritic cells, and the proportion of $\mathrm{pDCs}$ in blood. Spearman rank correlation was used to determine significance. Values for Spearman $r$ and $P$ values are presented for the different correlations in the table. 

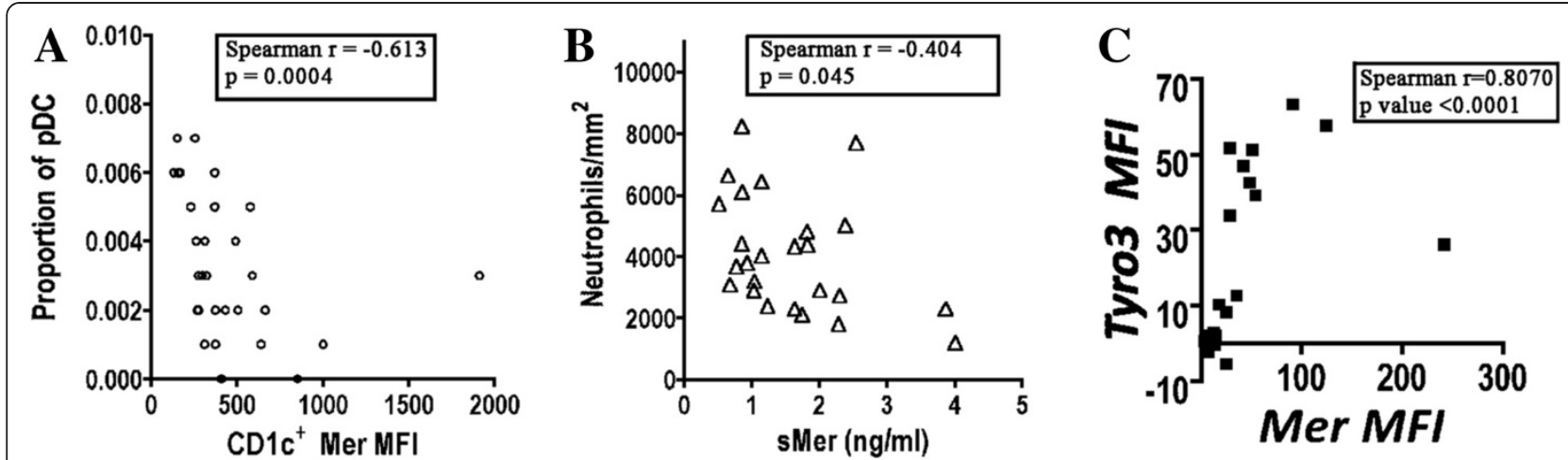

Figure 9 Correlates of Mer levels in peripheral blood of lupus patients. (A) Mer levels on CD1 $C^{+}$dendritic cells are negatively correlated with the proportion of pDCs in lupus blood. (B) sMer levels in blood are negatively correlated with the numbers of neutrophils in the blood of lupus patients. (C) Levels of Mer on the surface of $\mathrm{CD}^{+} \mathrm{T}$ cells are positively correlated with levels of Tyro 3.

lead to an increase in T-cell autoreactivity and increased autoimmune disease.

Mer is expressed in splenic NK and NKT cells in mice, and has been shown to have functional significance in the activation of NKT cells [31]. The present data indicate that expression on circulating human NK cells is negligible. We did not find enough NKT cells in the PBMC fraction to make any conclusion regarding Mer expression. Other subsets of leukocytes, including $\mathrm{CD}^{+}$ $\mathrm{T}$ cells and B cells, also had negligible levels of Mer expression, suggesting that Mer has no functional role in these cells under normal healthy circumstances.

We observed an increase in expression of Mer on $\mathrm{CD}_{1 \mathrm{c}^{+}} \mathrm{mDCs}$ and also in plasmacytoid DCs in lupus blood. These data suggest that no defect in Mer expression exists in lupus. The increase in Mer expression in DCs may reflect a response to an inflammatory environment in SLE akin to the activation of TAMR in response to TLR activation in monocytes [46]. The association of increased Mer expression with inflammation is also a feature of alveolar macrophages in the chronic lung inflammation seen in smokers [13] and also in monocytes in patients with septic shock [14]. In vitro experiments with human monocyte-derived DCs demonstrate that Axl is induced by type I interferon $[9,11]$. Analogously, therefore, Mer expression may also be a response to the type I interferon signature that characterizes lupus $[47,48]$. Thus increased Mer expression on DCs may represent a marker of IFN-I activity in lupus patients. This hypothesis is strongly supported by our results demonstrating a positive association between IFN-I activity and Mer levels on monocyte subsets and myeloid dendritic cells.

A notable negative correlation was noted between Mer expression on the $\mathrm{CD} 14^{\text {int }} \mathrm{CD} 16^{+}$subset of monocytes with the proportions of the same $\mathrm{CD} 14^{\text {int }} \mathrm{CD} 16^{+}$subset of monocytes, the $\mathrm{CD} 1 \mathrm{c}^{+} \mathrm{DC}$, and the $\mathrm{pDC}$ populations. This is consistent either with a selective killing of these cell subsets, or with an increased migration of the CD16 monocytes into the tissues. The former hypothesis suggests a lack of Mer-expressing phagocytes in certain lupus patients, which could be involved in the reported defect in the ability of macrophages from lupus patients to phagocytose apoptotic cells [17-20]. The latter hypothesis is supported by the established behavior of the $\mathrm{CD} 14^{\text {int }} \mathrm{CD} 16^{+}$ subset of these cells that is able to patrol the surface of the vascular endothelium and is more adherent than the $\mathrm{CD}_{14}{ }^{++}$subpopulation of $\mathrm{CD}_{16}{ }^{+}$and the classic $\mathrm{CD} 16^{-}$ monocytes [28] and hence is more likely to migrate from the vasculature into tissues.

Similarly, studies focusing on the total $\mathrm{CD} 16^{+}$monocyte population have demonstrated the increased adherent and transmigratory ability of these monocytes. Thus, the monocyte subsets expressing most Mer are more inclined to adhere to and transmigrate through the vascular endothelium [49-51], whereupon they may then partake in the phagocytosis of apoptotic cells in tissues. Mer expressions on all three monocyte subsets are positively associated with each other and with the Mer expressed on myeloid DC, arguing for a global regulation of Mer expression on monocyte and myeloid dendritic cells.

Remarkably, we also found an inverse correlation between the expression of Mer on the CD $14{ }^{\text {int }} \mathrm{CD} 16^{+}$ monocytes and the proportions of both the $\mathrm{CD}_{1} \mathrm{c}^{+}$myeloid and the plasmacytoid dendritic cells. Additionally, we found that the proportions of both pDCs and $\mathrm{CD} 1 \mathrm{c}^{+}$ myeloid dendritic cells were decreased in the SLE patient group compared with normal healthy subjects. The reduction in the numbers of $\mathrm{pDCs}$ has been reported [52] and may reflect recruitment from the peripheral blood to diseased tissues during disease episodes [53,54].

A role may exist for TAMR signaling in regulating autoimmunity via IFN-I signaling. In in vitro cultures of mouse bone marrow-derived dendritic cells, IFN- $\alpha$ induced Axl expression that downregulated inflammatory. 
Most of the homeostatic phagocytosis that takes place in an organism most probably occurs in solid tissues rather than in peripheral blood. It is likely that the expression of Mer is increased substantially in tissue-resident macrophages and hence that these macrophages are more efficient at removing apoptotic cells compared with peripheral blood monocytes. Although we did not address the question of how much Mer is necessary to evoke a functional phagocytic or regulatory response, it seems that the differences in Mer levels between the $\mathrm{CD}_{16}{ }^{+}$monocytes and the $\mathrm{CD} 16^{-}$monocytes contribute to the increased efficiency of the $\mathrm{CD} 16^{+}$monocytes at ingesting apoptotic neutrophils [34].

It is also possible that the increased expression of Mer on DCs in lupus patients may reflect a defect in Mer function in these cells, which could activate a compensatory pathway to upregulate Mer expression. Pertinent to this is our observation [55], and those of others [23,25], that increased levels of sMer are found in the blood of lupus patients compared with healthy control subjects. Increased levels of sAxl and sTyro3 have also been found in lupus patient blood [22,23], and all three soluble TAMRs can compete for the TAMR ligands Gas6 and protein $S$ to block Mer function. This, through competition for ligand, can lead to a suppression of membranebound Mer activation [29] and a decreased function of Mer in lupus.

In mouse models of lung disease, prevention of the proteolytic cleavage of Mer led to beneficial Mer-dependent pro-phagocytic and anti-inflammatory responses [56,57]. These results in mice suggest that increasing membranebound Mer activation may also have a beneficial effect in SLE.

Glucocorticoids induce a Mer/protein S-dependent mechanism of apoptotic cell removal in human monocytederived macrophages [58]. In keeping with this in vitro observation, Mer expression on monocytes of our SLE patients receiving prednisone correlated strongly with the dose of corticosteroid (Figure 6A). Unexpectedly, no overall difference was noted in Mer expression on the monocytes of those lupus patients taking prednisone compared with those not given prednisone. Patients not taking prednisone at all may differ clinically from those patients who merited prednisone, even small doses. This may be reflected in the normal or slightly elevated monocyte Mer expression in the presumably inactive patients not taking corticosteroids. Yet it was clear that prednisone increased Mer expression in a dose-dependent fashion in those patients sick enough to merit prednisone treatment.

We also found that prednisone-treated lupus patients had increased Mer expression on their $\mathrm{CD} \mathrm{c}^{+}$myeloid DCs. The apparent relation between steroid dose and monocyte and DC Mer expression parallels in vitro observations that glucocorticoids prominently induce Mer, together with a broader upregulation of proteins involved in the antiinflammatory phagocytic pathway specific for apoptotic cells $[33,34,59]$. The in vivo induction of Mer on monocytes, and especially dendritic cells, therefore may constitute an important part of the mechanism of immunosuppression induced by prednisone treatment.

In patients not being treated with prednisone, we found an association of sMer in blood with IFN-I activity levels. Because no direct upregulatory effect of type I IFNs was found on sMer release from in vitro cultures of monocytes [55], this association may depend on other disease-related factors. For example, this could reflect an increased activity in lupus blood, of specific proteases, such as ADAM10 and ADAM17 (TNF- $\alpha$-converting enzyme, TACE), which are capable of enzymatically converting membrane-bound Mer to soluble Mer. Our observations also suggest that a strong homeostatic mechanism may exist for Mer expression on the surface of monocytes and dendritic cells in peripheral blood.

We found that Tyro3 and Mer are expressed on CD4 ${ }^{+}$ $\mathrm{T}$ cells in some individuals with lupus. An increased Mer and Tyro 3 expression on $\mathrm{CD}^{+}$cells was noted in lupus patients compared with normal control subjects. Mer levels correlated with Tyro3 levels on the surface of $\mathrm{CD}_{4}^{+}$ $\mathrm{T}$ cells in lupus patients. The significance of this is unclear; however, it may be of interest because Mer has a prosurvival effect in the human Jurkat T-cell lymphoma [60] and also in other lymphomas overexpressing Mer [61], and therefore, it could potentially have a role in prolonging survival of autoreactive $\mathrm{T}$ cells in lupus. Clearly the role of TAMR in T-cell activation in inflammatory diseases deserves further study.

It will be interesting to look at other rheumatic diseases to see whether a similar regulation of Mer expression exists, and whether the Mer-expression pattern is unique to lupus.

Finally, although it is reasonable to believe that the expression of TAMR on blood leukocytes reflects the expression of Mer on immune cells in solid tissues, our study does not preclude the possibility that Mer expression is deficient in involved organs.

\section{Conclusions}

Our data show that no defect in Mer expression is present in SLE patients. In contrast, the increased levels of Mer on the surface of myeloid and plasmacytoid DCs may reflect the enhanced IFN-I inflammatory environment in SLE, and may also represent a compensatory response to reinstate immune tolerance and effect an antiinflammatory state. Also, because corticosteroid therapy enhances Mer expression on circulating monocytes and dendritic cells, this therapy may exert beneficial effects by enhancing phagocytic capacity for apoptotic 
debris and restoring peripheral immune tolerance via Mer in SLE patients.

\section{Additional file}

Additional file 1: Figure S1. Mer and Tyro3 expression in cell lines. (A) Cell lines U937, phorbol myristate acetate-stimulated THP-1, and Jurkat stained with monoclonal anti-Mer-PE. (B) K562 cells stained with monoclonal anti-Tyro3-PE Figure S2. Comparison of Mer and Tyro3 expression in leukocyte populations in the blood of normal healthy subjects and SLE patients. (A) Expression of Mer on lymphocyte populations in normal individuals and patients with SLE. (B) Expression of Tyro3 on leukocyte subpopulations from normal individuals and patients with SLE. Figure S3. Comparison of Mer expression in normal females with SLE patients and effect of gender on expression of Mer. (A) Mer expression levels on monocytes from normal females and patients with SLE. (B) Mer-expression levels on dendritic cells from normal females and patients with SLE. (C) Mer expression levels on monocytes from normal female and male subjects. (D) Mer-expression levels on dendritic cells from normal female and male subjects. Figure S4. Comparison of monocyte and dendritic cells proportions in normal healthy subjects and SLE patients. (A) Monocyte population proportions of peripheral blood mononuclear cells are similar between SLE and normal healthy subjects. The bars represent the mean values. (B) $\mathrm{CD} 1 \mathrm{C}^{+}$ and plasmacytoid dendritic cell proportions of peripheral blood mononuclear cells are reduced in patients with SLE compared with normal control subjects. Figure S5. Mer expression on monocytes, sMer in blood, and proportions of monocyte subsets correlate with IFN-I activity in SLE patients that do not receive prednisone. Mer levels on monocyte subsets. (A) $\mathrm{CD} 14^{++} \mathrm{CD} 16^{+}$, (B) CD14intCD16 ${ }^{+}$, and (C) CD $14^{++} \mathrm{CD} 16$ and sMer levels in (D) plasma, positively correlate with interferon activity. Proportions of monocyte subsets correlate with IFN-I activity, negatively for (E) CD14intCD16 ${ }^{+}$monocytes, and positively for (F) CD14 ${ }^{++} \mathrm{CD} 16$ monocytes

\section{Abbreviations}

mDC: myeloid dendritic cell; Mer: Mer receptor kinase; NK: natural killer; PBMC: peripheral blood mononuclear cell; pDC: plasmacytoid dendritic cell; SLE: systemic lupus erythematosus; sMer: soluble Mer receptor; TAMR: TAM receptor family of membrane tyrosine kinase; Tyro3: tyrosine receptor kinase 3.

\section{Competing interests}

Philip Cohen and Brendan Hilliard declare that they receive funding for other research studies from Janssen Research and Development. The remaining authors declare that they have no competing interests.

\section{Author' contributions}

BAH: conception, design, data collection, analysis, manuscript writing, and final approval of the manuscript. GZ: analysis, critical revision of the manuscript, MU: data collection and analysis, critical revision, and final approval of the manuscript. MKL: data analysis. critical revision, and final approval of the manuscript. JS:, data collection and analysis, critical revision, and final approval of the manuscript. PLC: conception, design, analysis, critical revision, and final approval of manuscript. All authors read and approved the final manuscript.

\section{Acknowledgements}

This study was supported by the Philadelphia Autoimmunity Center of Excellence (NIAID U19AI 10822726) and a bequest from Alberta C. Wicks. We acknowledge the assistance of Xiaoxuan Fan of the Temple University Flow Cytometry Core Facility in the operation of the LSRII flow cytometer. We acknowledge the helpful discussions with Michael F. Denny, Ph.D., of the Rheumatology Section of the Department of Medicine at Temple University. We also acknowledge the help of Jarrat Jordan, Ph.D., of Janssen Research and Development, LLC, who facilitated the utilization of the IFN-I activity assay in our analysis of patient plasma.

\section{Author details}

'Section of Rheumatology, Department of Medicine, Temple University School of Medicine, 3322 North Broad Street, Philadelphia, PA 19140, USA. ${ }^{2}$ Temple Autoimmunity Center, Temple University School of Medicine, 3500 North Broad Street, Philadelphia, PA 19140, USA. ${ }^{3}$ Department of Public Health, Temple University, Philadelphia, PA 19122, USA. ${ }^{4}$ Janssen Research and Development, LLC, Spring House, PA 19002, USA.

Received: 27 August 2013 Accepted: 6 March 2014

Published: 21 March 2014

\section{References}

1. Lai $C$, Lemke G: An extended family of protein-tyrosine kinase genes differentially expressed in the vertebrate nervous system. Neuron 1991 6:691-704.

2. Lemke $\mathrm{G}$, Burstyn-Cohen T: TAM receptors and the clearance of apoptotic cells. Ann N Y Acad Sci 2010, 1209:23-29.

3. Scott RS, McMahon EJ, Pop SM, Reap EA, Caricchio R, Cohen PL, Earp HS, Matsushima GK: Phagocytosis and clearance of apoptotic cells is mediated by MER. Nature 2001, 411:207-211.

4. Anderson HA, Maylock CA, Williams JA, Paweletz CP, Shu H, Shacter E: Serum-derived protein $\mathrm{S}$ binds to phosphatidylserine and stimulates the phagocytosis of apoptotic cells. Nat Immunol 2003, 4:87-91.

5. Lu Q, Lemke $\mathrm{G}$ : Homeostatic regulation of the immune system by receptor tyrosine kinases of the Tyro 3 family. Science (New York) 2001 293:306-311.

6. Rothlin CV, Lemke G: TAM receptor signaling and autoimmune disease. Curr Opin Immunol 2010, 22:740-746.

7. Sen P, Wallet MA, Yi Z, Huang Y, Henderson M, Mathews CE, Earp HS, Matsushima G, Baldwin AS Jr, Tisch RM: Apoptotic cells induce Mer tyrosine kinase-dependent blockade of NF-kappaB activation in dendritic cells. Blood 2007, 109:653-660.

8. Shao WH, Zhen Y, Rosenbaum J, Eisenberg RA, McGaha TL, Birkenbach M, Cohen PL: A protective role of Mer receptor tyrosine kinase in nephrotoxic serum-induced nephritis. Clin Immunol (Orlando) 2010 136:236-244.

9. Sharif MN, Sosic D, Rothlin CV, Kelly E, Lemke G, Olson EN, Ivashkiv LB: Twist mediates suppression of inflammation by type I IFNs and Axl. J Exp Med 2006, 203:1891-1901.

10. Neubauer A, Fiebeler A, Graham DK, O'Bryan JP, Schmidt CA, Barckow P, Serke S, Siegert W, Snodgrass HR, Huhn D: Expression of axl, a transforming receptor tyrosine kinase, in normal and malignant hematopoiesis. Blood 1994, 84:1931-1941.

11. Scutera S, Fraone T, Musso T, Cappello P, Rossi S, Pierobon D, Orinska Z, Paus R, Bulfone-Paus S, Giovarelli M: Survival and migration of human dendritic cells are regulated by an IFN-alpha-inducible Axl/Gas6 pathway. J Immunol 2009, 183:3004-3013.

12. Seitz HM, Camenisch TD, Lemke G, Earp HS, Matsushima GK: Macrophages and dendritic cells use different Axl/Mertk/Tyro3 receptors in clearance of apoptotic cells. J Immunology 2007, 178:5635-5642.

13. Kazeros A, Harvey BG, Carolan BJ, Vanni H, Krause A, Crystal RG: Overexpression of apoptotic cell removal receptor MERTK in alveolar macrophages of cigarette smokers. Am J Respir Cell Mol Biol 2008, 39:747-757.

14. Guignant C, Venet F, Planel S, Demaret J, Gouel-Cheron A, Nougier C, Friggeri A, Allaouchiche B, Lepape A, Monneret G: Increased MerTK expression in circulating innate immune cells of patients with septic shock. Intensive Care Med 2013, 39:1556-1564.

15. Strick DJ, Feng W, Vollrath D: Mertk drives myosin II redistribution during retinal pigment epithelial phagocytosis. Invest Ophthalmol Vis Sci 2009, 50:2427-2435

16. Kuenkele S, Beyer TD, Voll RE, Kalden JR, Herrmann M: Impaired clearance of apoptotic cells in systemic lupus erythematosus: challenge of $\mathrm{T}$ and $\mathrm{B}$ cell tolerance. Curr Rheumatol Rep 2003, 5:175-177.

17. Baumann I, Kolowos W, Voll RE, Manger B, Gaipl U, Neuhuber WL, Kirchner T, Kalden JR, Herrmann M: Impaired uptake of apoptotic cells into tingible body macrophages in germinal centers of patients with systemic lupus erythematosus. Arthritis Rheum 2002, 46:191-201.

18. Ren Y, Tang J, Mok MY, Chan AW, Wu A, Lau CS: Increased apoptotic neutrophils and macrophages and impaired macrophage phagocytic 
clearance of apoptotic neutrophils in systemic lupus erythematosus. Arthritis Rheum 2003, 48:2888-2897.

19. Tas SW, Quartier P, Botto M, Fossati-Jimack L: Macrophages from patients with SLE and rheumatoid arthritis have defective adhesion in vitro, while only SLE macrophages have impaired uptake of apoptotic cells. Ann Rheum Dis 2006, 65:216-221.

20. Herrmann M, Voll RE, Zoller OM, Hagenhofer M, Ponner BB, Kalden JR: Impaired phagocytosis of apoptotic cell material by monocyte-derived macrophages from patients with systemic lupus erythematosus. Arthritis Rheum 1998, 41:1241-1250.

21. Lu L, Kaliyaperumal A, Boumpas DT, Datta SK: Major peptide autoepitopes for nucleosome-specific T cells of human lupus. J Clin Invest 1999, 104:345-355.

22. Gheita TA, Bassyouni IH, Bassyouni RH: Plasma concentrations of growth arrest specific protein 6 and the soluble form of its tyrosine kinase receptor $\mathrm{Axl}$ in patients with systemic lupus erythematosus and Behcets disease. J Clin Immunol 2012, 32:1279-1286.

23. Recarte-Pelz P, Tassies D, Espinosa G, Hurtado B, Sala N, Cervera R, Reverter JC, de Frutos PG: Vitamin K-dependent proteins GAS6 and protein $S$ and TAM receptors in patients of systemic lupus erythematosus: correlation with common genetic variants and disease activity. Arthritis Res Ther 2013, 15:R41.

24. Suh $\mathrm{CH}$, Hilliard B, Li S, Merrill JT, Cohen PL: TAM receptor ligands in lupus: protein $\mathrm{S}$ but not Gas6 levels reflect disease activity in systemic lupus erythematosus. Arthritis Res Ther 2010, 12:R146.

25. Wu J, Ekman C, Jonsen A, Sturfelt G, Bengtsson AA, Gottsater A, Lindblad B, Lindqvist $E$, Saxne T, Dahlback B: Increased plasma levels of the soluble Mer tyrosine kinase receptor in systemic lupus erythematosus relate to disease activity and nephritis. Arthritis Res Ther 2011, 13:R62.

26. Bombardier C, Gladman DD, Urowitz MB, Caron D, Chang CH: Derivation of the SLEDAl, a disease activity index for lupus patients: The Committee on Prognosis Studies in SLE. Arthritis Rheum 1992, 35:630-640.

27. Ziegler-Heitbrock L, Ancuta P, Crowe S, Dalod M, Grau V, Hart DN, Leenen PJ, Liu YJ, MacPherson G, Randolph GJ, Scherberich J, Schmitz J, Shortman K, Sozzani S, Strobl H, Zembala M, Austyn JM, Lutz MB: Nomenclature of monocytes and dendritic cells in blood. Blood 2010, 116:e74-e80.

28. Cros J, Cagnard N, Woollard K, Patey N, Zhang SY, Senechal B, Puel A, Biswas SK, Moshous D, Picard C, Jais JP, D'Cruz D, Casanova JL, Trouillet C: Human CD14dim monocytes patrol and sense nucleic acids and viruses via TLR7 and TLR8 receptors. Immunity 2010, 33:375-386.

29. Sather S, Kenyon KD, Lefkowitz JB, Liang X, Varnum BC, Henson PM, Graham DK: A soluble form of the Mer receptor tyrosine kinase inhibits macrophage clearance of apoptotic cells and platelet aggregation. Blood 2007, 109:1026-1033.

30. Ytterberg SR, Schnitzer TJ: Serum interferon levels in patients with systemic lupus erythematosus. Arthritis Rheum 1982, 25:401-406.

31. Behrens EM, Gadue P, Gong SY, Garrett S, Stein PL, Cohen PL: The Mer receptor tyrosine kinase: expression and function suggest a role in innate immunity. Eur J Immunol 2003, 33:2160-2167.

32. Shao $\mathrm{WH}$, Zhen $\mathrm{Y}$, Eisenberg RA, Cohen PL: The Mer receptor tyrosine kinase is expressed on discrete macrophage subpopulations and mainly uses Gas6 as its ligand for uptake of apoptotic cells. Clin Immunol (Orlando) 2009, 133:138-144.

33. Zahuczky G, Kristof E, Majai G, Fesus L: Differentiation and glucocorticoid regulated apopto-phagocytic gene expression patterns in human macrophages: role of Mertk in enhanced phagocytosis. PLoS One 2011, 6:e21349.

34. Zizzo G, Hilliard BA, Monestier M, Cohen PL: Efficient clearance of early apoptotic cells by human macrophages requires M2c polarization and MerTK induction. J Immunology 2012, 189:3508-3520.

35. Ziegler-Heitbrock L, Hofer TP: Toward a refined definition of monocyte subsets. Front Immunol 2013, 4:23.

36. Scherberich JE, Nockher WA: CD14++ monocytes, CD14+/CD16+ subset and soluble CD14 as biological markers of inflammatory systemic diseases and monitoring immunosuppressive therapy. Clin Chem Lab Med 1999, 37:209-213.

37. Skrzeczynska-Moncznik J, Bzowska M, Loseke S, Grage-Griebenow E, Zembala M, Pryjma J: Peripheral blood CD14high CD16+ monocytes are main producers of IL-10. Scand J Immunol 2008, 67:152-159.

38. Wong KL, Tai JJ, Wong WC, Han H, Sem X, Yeap WH, Kourilsky P, Wong SC: Gene expression profiling reveals the defining features of the classical, intermediate, and nonclassical human monocyte subsets. Blood 2011, 118:e16-e31.
39. Rossol M, Kraus S, Pierer M, Baerwald C, Wagner U: The CD14(bright) CD16+ monocyte subset is expanded in rheumatoid arthritis and promotes expansion of the Th17 cell population. Arthritis Rheum 2012, 64:671-677.

40. Rogacev KS, Seiler S, Zawada AM, Reichart B, Herath E, Roth D, Ulrich C, Fliser D, Heine GH: CD14++CD16+ monocytes and cardiovascular outcome in patients with chronic kidney disease. Eur Heart J 2011, 32:84-92.

41. Heine GH, Ulrich C, Seibert E, Seiler S, Marell J, Reichart B, Krause M, Schlitt A, Kohler H, Girndt M: CD14(++)CD16+ monocytes but not total monocyte numbers predict cardiovascular events in dialysis patients. Kidney Int 2008, 73:622-629.

42. Rogacev KS, Cremers B, Zawada AM, Seiler S, Binder N, Ege P, GrosseDunker G, Heisel I, Hornof F, Jeken J, Rebling NM, Ulrich C, Scheller B, Böhm M, Fliser D, Heine GH: CD14++CD16+ monocytes independently predict cardiovascular events: a cohort study of 951 patients referred for elective coronary angiography. J Am Coll Cardiol 2012, 60:1512-1520.

43. Mikolajczyk TP, Skrzeczynska-Moncznik JE, Zarebski MA, Marewicz EA, Wisniewska AM, Dzieba M, Dobrucki JW, Pryjma JR: Interaction of human peripheral blood monocytes with apoptotic polymorphonuclear cells. Immunology 2009, 128:103-113.

44. Yi Z, Li L, Matsushima GK, Earp HS, Wang B, Tisch R: A novel role for c-Src and STAT3 in apoptotic cell-mediated MerTK-dependent immunoregulation of dendritic cells. Blood 2009, 114:3191-3198.

45. Wallet MA, Sen P, Flores RR, Wang Y, Yi Z, Huang Y, Mathews CE, Earp HS, Matsushima G, Wang B, Tisch R: MerTK is required for apoptotic cell-induced T cell tolerance. J Exp Med 2008, 205:219-232.

46. Rothlin CV, Ghosh S, Zuniga El, Oldstone MB, Lemke G: TAM receptors are pleiotropic inhibitors of the innate immune response. Cell 2007, 131:1124-1136

47. Preble OT, Black RJ, Friedman RM, Klippel JH, Vilcek J: Systemic lupus erythematosus: presence in human serum of an unusual acid-labile leukocyte interferon. Science (New York) 1982, 216:429-431.

48. Baechler EC, Batliwalla FM, Karypis G, Gaffney PM, Ortmann WA, Espe KJ, Shark KB, Grande WJ, Hughes KM, Kapur V, Gregersen PK, Behrens TW: Interferon-inducible gene expression signature in peripheral blood cells of patients with severe lupus. Proc Natl Acad Sci U S A 2003 100:2610-2615.

49. Aspinall Al, Curbishley SM, Lalor PF, Weston CJ, Liaskou E, Adams RM, Holt $A P$, Adams DH: CX(3)CR1 and vascular adhesion protein-1-dependent recruitment of $\mathrm{CD} 16(+)$ monocytes across human liver sinusoidal endothelium. Hepatology (Baltimore) 2010, 51:2030-2039.

50. Garibaldi S, Barisione C, Ghigliotti G, Spallarossa P, Barsotti A, Fabbi P, Corsiglia L, Palmieri D, Palombo D, Brunelli C: Soluble form of the endothelial adhesion molecule CD146 binds preferentially CD16+ monocytes. Mol Biol Rep 2012, 39:6745-6752.

51. Ramirez R, Carracedo J, Merino A, Soriano S, Ojeda R, Alvarez-Lara MA, Martin-Malo A, Aljama P: CD14 + CD16+ monocytes from chronic kidney disease patients exhibit increased adhesion ability to endothelial cells. Contrib Nephrol 2011, 171:57-61.

52. Cederblad B, Blomberg S, Vallin H, Perers A, Alm GV, Ronnblom L: Patients with systemic lupus erythematosus have reduced numbers of circulating natural interferon-alpha-producing cells. J Autoimmun 1998, $11: 465-470$

53. Blomberg S, Eloranta ML, Cederblad B, Nordlin K, Alm GV, Ronnblom L: Presence of cutaneous interferon-alpha producing cells in patients with systemic lupus erythematosus. Lupus 2001, 10:484-490.

54. Tucci M, Quatraro C, Lombardi L, Pellegrino C, Dammacco F, Silvestris F: Glomerular accumulation of plasmacytoid dendritic cells in active lupus nephritis: role of interleukin-18. Arthritis Rheum 2008, 58:251-262.

55. Zizzo G, Guerrieri J, Dittman LM, Merrill JT, Cohen PL: Circulating levels of soluble MER in lupus reflect M2c activation of monocytes/macrophages, autoantibody specificities and disease activity. Arthritis Res Ther 2013, 15:R212.

56. Choi JY, Park HJ, Lee YJ, Byun J, Youn YS, Choi JH, Woo SY, Kang JL: Upregulation of Mer receptor tyrosine kinase signaling attenuated lipopolysaccharide-induced lung inflammation. J Pharmacol Exp Ther 2013, 344:447-458

57. Lee YJ, Lee SH, Youn YS, Choi JY, Song KS, Cho MS, Kang JL: Preventing cleavage of Mer promotes efferocytosis and suppresses acute lung injury in bleomycin treated mice. Toxicol Appl Pharmacol 2012, 263:61-72.

58. McColl A, Bournazos S, Franz S, Perretti M, Morgan BP, Haslett C, Dransfield I: Glucocorticoids induce protein S-dependent phagocytosis of apoptotic neutrophils by human macrophages. J Immunol 2009, 183:2167-2175. 
59. Ehrchen J, Steinmuller L, Barczyk K, Tenbrock K, Nacken W, Eisenacher M, Nordhues U, Sorg C, Sunderkotter C, Roth J: Glucocorticoids induce differentiation of a specifically activated, anti-inflammatory subtype of human monocytes. Blood 2007, 109:1265-1274.

60. Brandao LN, Winges A, Christoph S, Sather S, Migdall-Wilson J, Schlegel J, McGranahan A, Gao D, Liang X, Deryckere D, Graham DK: Inhibition of MerTK increases chemosensitivity and decreases oncogenic potential in T-cell acute lymphoblastic leukemia. Blood Cancer J 2013, 3:e101.

61. Keating AK, Salzberg DB, Sather S, Liang X, Nickoloff S, Anwar A, Deryckere D, Hill K, Joung D, Sawczyn KK, Park J, Curran-Everett D, McGavran L, Meltesen L, Gore L, Johnson GL, Graham DK: Lymphoblastic leukemia/lymphoma in mice overexpressing the Mer (MerTK) receptor tyrosine kinase. Oncogene 2006, 25:6092-6100

doi:10.1186/ar4517

Cite this article as: Hilliard et al:: Increased expression of Mer tyrosine kinase in circulating dendritic cells and monocytes of lupus patients: correlations with plasma interferon activity and steroid therapy. Arthritis Research \& Therapy 2014 16:R76.

\section{Submit your next manuscript to BioMed Central and take full advantage of:}

- Convenient online submission

- Thorough peer review

- No space constraints or color figure charges

- Immediate publication on acceptance

- Inclusion in PubMed, CAS, Scopus and Google Scholar

- Research which is freely available for redistribution 